\title{
Determinants of Tax Effort and Tax Capacity in Jordan During the Period (2000-2017)
}

\author{
Saleh Yahya Al-Freijat ${ }^{1,}$, Mohammad Khalil Adeinat ${ }^{2}$ \\ ${ }^{1}$ Department of Business Economics, School of Graduate Studies, University of Jordan, Amman, Jordan \\ ${ }^{2}$ Department of Business Economics, School of Business, University of Jordan, Amman, Jordan
}

Email address:

Salehfrejat89@hotmail.com (S. Y. Al-freijat),Aorc2012@gmail.com (M. K. Adeinat)

${ }^{*}$ Corresponding author

\section{To cite this article:}

Saleh Yahya Al-Freijat, Mohammad Khalil Adeinat. Determinants of Tax Effort and Tax Capacity in Jordan During the Period (2000-2017). International Journal of Business and Economics Research. Vol. 9, No. 1, 2020, pp. 1-10. doi: 10.11648/j.ijber.20200901.11

Received: December 15, 2019; Accepted: January 3, 2020; Published: January 17, 2020

\begin{abstract}
The main objective of this study was to measure the tax capacity and tax effort in Jordan by using cross-sectional time series data for 59 countries during the period (2000-2017), where the modal was estimated by the least squares method and the normal results of the study, (OLS), the result of the study showed a positive relationship between the tax burden and the share of exports of GDP, while the relationship was inverse with the value added of the manufacturing sector, per capita income and the share of the services sector of GDP. As for the estimated tax effort, the results showed that the data of Jordan were compensated in the estimated standard model where the tax capacity in Jordan in 2017 was about $16.1 \%$, this means that Jordan is close to the upper limits of the tax capacity; in 2017 the tax burden has reached about 15.7\%. Taking into account the impact of the procedures that the government has taken since the begging of 2018, especially the sales tax and the special taxes on oil, this means that Jordan is close to the limits of tax exhaustion. The results of the study also showed that the tax effort in Jordan is high, thus means that the category that pays taxes pays more than its capacity taxes, and these counts as an exhaustion on the productive sectors, which negatively affects the competitiveness. The study recommended the importance of the effective utilizing of tax capacity for individuals and for the economy and maintains acceptable levels of tax effort and not to exceed these levels.
\end{abstract}

Keywords: Tax Effort, Tax Burden, Tax Capacity, GDP

\section{Introduction}

The subject of tax capacity and tax effort is of great importance in modern financial studies, in the search of the optimum size of tax revenues, based on achieving the principle of equity that takes into account the economical, financial and social conditions of society, based on that the performance of the tax structure and its ability to increase tax revenues are assessed. The Jordanian economy has witnessed many economical and financial crises, represented by the increase in the public debt ratio and the increase in the state budget deficit, as a result of the inflation of government expenditures. In addition, the Jordanian economy has been affected by the deteriorating political conditions in the region. Hence, the Jordanian government has sought to improve economical performance, especially in recent years through the adoption of a national correction program in cooperation with the International Monetary Fund (IMF), which focuses on a series of reforms, especially tax reforms.

Several tax reforms have been implemented in Jordan aimed at balancing the tax burden on citizens and the business sector, facilitating the process of payment and collection of tax, and keep abreast of the latest tax systems that focus on attracting foreign direct investment, and to achieve economic growth rather than a tool for collection only.

IMF considered being the first institution that measured the tax effort in Jordan 1960s. In Jordan, the importance of domestic revenues, especially taxation, has emerged in recent years, and this interest has increased due to several factors, and the most important factor is the continuous decline in external grants and the permanent deficit in the budget, which affected the ability of the Jordanian economy to grow 
and settle,[1].

In the context of the recent tax reform adopted by the state, several issues were raised concerning the expected effects on the public budget, economic growth, and economic efficiency and improving the efficiency of tax collection.

This study comes to measure the tax capacity and tax effort in Jordan in an attempt to understand and analyze it in a comprehensive framework that takes into account all the associated effects and implications. The importance of this study is that taxes are an important source for the government to cover its expenses, and one of the factors affecting growth and economic stability. Individuals always seek to evade taxes because they believe the burden is huge.

This is mainly due to the low per capita income and the low level of tax awareness, because it is one of the topics that concern the mobilization and allocation of financial resources available for the implementation of programs and projects that the government seeks to implement with the growing sense in many Arab countries that the financing role of taxes is no longer appropriate to meet their ambitions, which made many of the 'move towards reforming and developing their tax systems.

This study aimed to estimate the percentage of tax burden and tax capacity beard by the Jordanian citizen, and to measure the possibility of new taxes or increasing or decreasing existing tax rates under current variables.

The study's method was based on measuring the tax performance indicators and their suitability to the economic situation and the current economic and social trends, especially in the recent tax reforms. The tax burden has been calculated from the reality of the data and the estimation of a standard model for the calculation of tax capacity through the use of cross-sectional data for 59 countries during the period (2000_2017) by (1062) views, a sample of time series data (Panel Data) was estimated, and then the tax effort was calculated based on the tax burden and tax capacity estimates. The results were extracted using the Eviews program, then using Jordan's data in the estimated model for obtaining the amount of tax capacity and tax effort in Jordan.

\section{Theoretical Framework and Literature Review}

The tax burden index reflects the role of taxes in a country's economy and reflects the taxes incurred by citizens and businesses sectors [2]. Tax capacity and tax effort are also the most fundamental tools in analyzing tax policies, to identify positive and negative impacts and compare them with other economic elements. The impact of tax policy may extend to demand, gross supply, consumption, money and employment [3].

The first famous economist who addressed the basic rules of taxation is Adam Smith in his book "The Wealth of Nations", pointing out that it is the duty of reasonable citizens in any country to support their governments commensurate with their respective capacities. His analysis is based on taxation of four basic principles: equality, certainty, appropriateness, and economics.

In terms of equality or justice, he assumed that individuals' contribution to state expenditures is based on their relative ability to pay the tax. Thus, low-income earners are exempt from taxation in order to ensure minimum living standards. And then find relative segments according to income.

In terms of certainty, he meant that the rate of tax imposed and the date of payment and how to collect it and all the procedures related to it known to all. Taxation must be stable in the sense that the amendments are limited and at intervals and are not subject to constant changes. Furthermore, he asserted that tax legislation should be clear.

In terms of appropriateness, the collection of taxes must be characterized by high efficiency in terms of time and the most appropriate way to pay the tax, in other words set an appropriate date for the payment of the tax and that the collection procedures appropriate to the circumstances of the taxpayer.

Finally, the economy means the cost of tax, which means what the state incurs in assessing and collecting the tax, and what is left of the net proceeds, these expenditures should not minimize much of the tax revenue in such a way that decrease the possibilities of the state benefiting from it [4].

There are many measures used in estimating tax burdens, their flexibility and efficiency. The following are the main indicators used in assessing tax performance in terms of burden, capacity and effort:

\section{Tax Burden}

Interest in studying the tax burden has increased since the middle of the last century as an important indicator reflecting the performance of the tax system, showing the total taxation incurred by society during a specific period of time to finance public activity [5]. In other words, it is the total taxes that society actually pays, attributed to one of the indicators that indicate the income of society such as GDP or GNP [6].

$$
\mathrm{TB}=\mathrm{TR} / \mathrm{GDP}
$$

Where:

TR: Total taxes already paid by the community.

GDP: Gross domestic product.

TB: tax burden.

The tax burden can be divided into categories as follows:

A - General tax burden: Represents total taxes relative to GDP.

B - Individual tax burden: This includes the per capita tax as expressed in monetary units, and the proportion of this share of per capita GDP, [7].

Tax Capacity

Analysis of the tax burden index was not sufficient to analyze the appropriateness of the tax. Therefore, the concept of tax capacity or tax burden emerged as an indicator of analysis that balances the government's need for tax to cover its expenses, its ability to collect that tax and the ability of individuals to pay taxes. It is defined as the maximum revenue that can be collected through taxes, taking into account the size and structure of GDP, the amount of public 
expenditure, its level of productivity, the ability of individuals to afford taxes, and the government's ability to collect them [8]. That is, tax capacity represents the maximum amount of tax revenue that can be collected in a given country due to its economical, social, institutional and demographic characteristics, and the potential tax collection represents the maximum amount of revenue that can be obtained through the applicable tax system [9].

Tax Effort

It is the tax revenue generated (actual tax burden) relative to the estimated tax capacity (optimal tax burden). That is, the ratio between the share of actual tax collection in GDP and the expected tax capacity. [10], it is calculated as follows:

$$
\mathrm{TE}=\mathrm{TB} / \mathrm{TC}
$$

Where:

TE: Tax effort.

TB: actual tax burden.

TC: Tax capacity.

This indicator reflects the extent to which society is taxed, or the amount of tax capacity used by the state. When a single tax effort is exceeded, which means that the state is using its tax approach well to increase tax revenue, this means that the taxes actually paid outweigh the tax capacity of the community, which means the occurrence of tax exhaustion, and their degree varies depending on whether they move farther or closer to the value of one, whereas a low tax effort is a situation where the index is less than the value of one, suggesting that the state may have a relatively large range or potential to increase tax revenue.

Countries can be classified according to the tax effort and actual tax collection criteria into four different groups:

A. Low tax collection, low tax effort.

B. Collection of high taxes, high tax effort.

C. Low tax collection and a high tax effort.

D. High tax collection, low tax effort [10].

Measuring Tax Capacity and Tax Effort:

In order to enhance the government's ability to impose additional taxes or raise current tax rates within the maximum capacity of taxpayers, measuring the tax effort and tax burden related to tax capacity becomes important. It in turn provides important information to assist the government in its endeavors, as well as enables decision makers to determine a fixed tax burden with the state's tax capacity. Actual tax revenue as a percentage of GDP is considered as one of the most common tax measures used to compare taxes. The most important advantages of this procedure are the ease of obtaining it and giving a quick overview of the state's tax direction. However, as noted by [11], this procedure is more suitable for studies that focus on the states which are close to each other in terms of economic characteristics and structures.

Measuring the tax effort depends on the tax capacity and tax burden. Thus, calculating the tax burden and estimating the tax capacity helps in measuring the tax effort. The tax effort is also affected by some factors and determinants, which differ from developing and developed countries, and between the countries of each group due to fluctuations in productivity and income. [12]. It should be noted that the determinants of the tax effort are the same as those of tax capacity and tax burden. The determinants of both are based on the idea that dividing tax by GDP is a function of a number of other determinants [13].

The tax system in Jordan:

The Ministry of Finance has made several amendments to its tax system with the aim of increasing collection efficiency, fair distribution and stimulating sectors and other objectives. After the economic crisis that hit the Jordanian economy at the end of 1989, the Jordanian government carried out a comprehensive review of the tax regulations adopted, especially in light of the emergence of many weaknesses, such as the complexity, the difficulty of management, poor compliance, and tax exemptions that contradict the standards of efficiency and effectiveness [14], which in turn contributed to creating distortions in the tax system. Hence, the Jordanian government improved the structural and institutional structures of the tax system. The tax system became focused on sales tax, which started on a small scale as excise tax in 1926 and ended with the current form of sales tax which came into effect on January 1, 2001 under Law No. (36) in 2000, which is similar to the globally applicable Value Added Tax (VAT) system.

The government also made amendments to the Income Tax Law in 2009 by adopting a unified tax system, which reflected negatively on the amount of tax collected in 2010 and 2011, and more recently in 2014, another amendment to the Income Tax Law included changes in exemptions and rates. A new amendment was added in 2018. According to the draft law, the exemptions will include those whose income is less than 9,000 dinars per person and 18,000 dinars for the family. (Law amending the Income Tax Law for the year 2018, which shall be read in conjunction with Law No. 34 of 2014 and shall come into force on 1/1/2019).

System Structure in Jordan:

Jordan's tax system consists mainly of direct and indirect taxes, with an emphasis on indirect taxes, as it is the main source of government revenue. Indirect taxes reached a relative importance of $68 \%$ in 2017, while the relative importance of customs duties constituted $7 \%$ and income and profits taxes at $22 \%$ during 2017 . Hence, the tax structure in Jordan is highly dependent on sales tax. And, to a limited extent, income tax, which places greater burdens on the middle class. Tax revenues grew steadily after 1989 as a result of the correction programs adopted by Jordan in cooperation with the (IMF), but returned to slow growth rates during the period (2000-2017), due to Jordan's impact on the repercussions of the global financial crisis and unfavorable conditions, which forced Jordan was again in 2012 on a correction program with the (IMF), which contributed to the increase in tax revenue growth as the Ministry of Finance reviewed tax policies, reviewed several tax exemptions, and raised tax on certain luxury goods. These reforms have placed additional burdens on the consumer as a result of targeting severe tax adjustments. Figure 1 shows that total tax revenue has slowed from 2000 to 2003 , rising steadily since 
2004. Despite the reforms, the tax system is still unable to finance increased government expenditures. This is due to several reasons, including tax evasion and the lack of public services provided by the government. Government expenditures account for about $65 \%$ of wages and salaries for taxes in Jordan that the tax reform led to increased collections, especially from income tax, which witnessed a noticeable rise during the period (2009-2014) due to the focus on increasing collections rather than stimulating Economic growth.

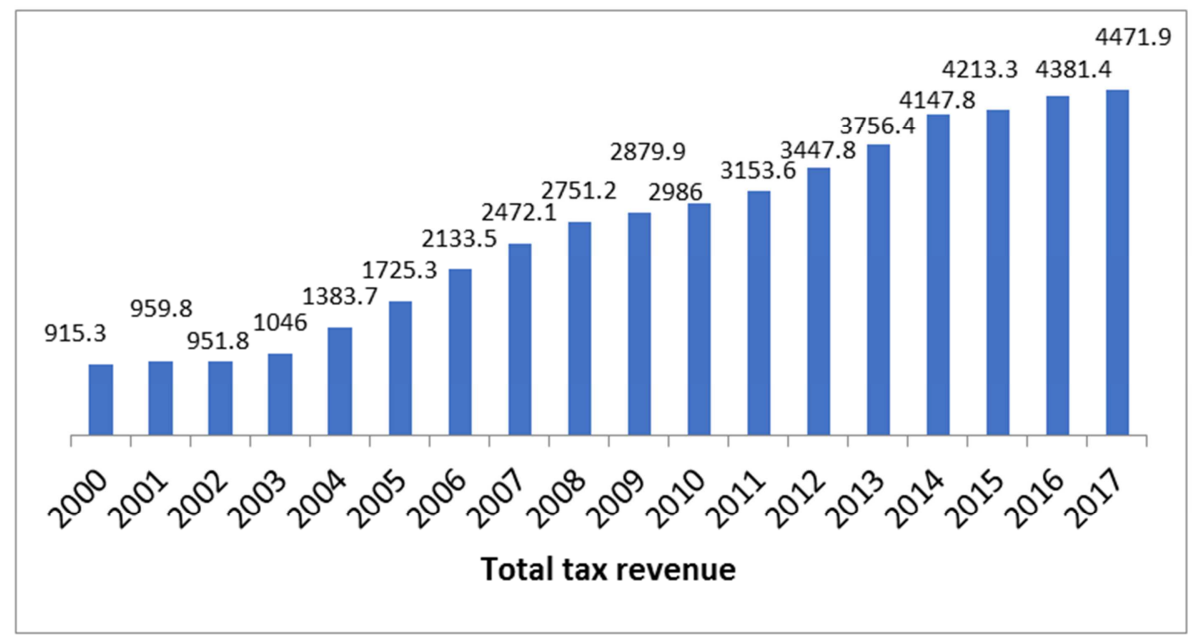

Source: Ministry of Finance. Government Finance Bulletin Various Issues.

Figure 1. Total tax revenues (million JD) during the period (2000-2017).

\section{Types of Taxes in Jordan:}

Taxes on income and profits:

Income and profits tax in Jordan has undergone several developments, including in 2002, where the Ministry of Finance reduced the number of taxable segments from six to four, as well as reducing tax rates from $30 \%$ to $25 \%$ on individuals, while keeping them on banks and institutions of $35 \%$, and cancelled the tax on profit stocks. The amendment came within the framework of Jordan's accession to the World Trade Organization. In 2009, the government issued a temporary income tax law, in which exemptions amounting to 12,000 dinars per person and 12,000 dinars for dependents (24,000 dinars per family) were approved, which reflected negatively on income tax revenues. The law subjected banks to $30 \%$, telecom, broker, insurance, financial, exchange and leasing companies to $24 \%$, while other companies and sectors, including industry and commerce, were subject to 14\%. Farmers and cooperatives were exempted, while agricultural companies were exempted from the first 75,000 dinars from their income. The government aimed through this amendment at improving the investment climate, stimulating economic growth and enhancing the competitiveness of the Jordanian economy. As a result of Jordan's exposure to difficult circumstances represented in the unprecedented high budget deficit and indebtedness, the government in 2015 issued a new income tax law, according to which this income taxable income is 12000 JD per year, and $24000 \mathrm{JD}$ and for the family with granting natural person exemption treatment, education and interest on loans should not exceed $4000 \mathrm{JD}$.

The law also provides for the deduction of income tax $7 \%$ for each dinar from the first 10,000 dinars above the taxable income, $14 \%$ for each dinar of the next ten thousand dinars, and $20 \%$ for each dinar that followed. The amendment of the law in 2014 increased revenues from income tax to about 938.4 million dinars in 2017. However, these measures taken by the government to amend the income tax law have negatively impacted the economy and thus reduced economic growth.

Taxes on financial transactions (property sales tax)

Tax revenues on financial transactions witnessed a recovery in the period (2005-2008) as a result of the boom experienced by Jordan and the improvement of market performance, and consequently the volume of financial transactions, but decreased during the period of the global financial crisis and the consequent government exemptions to activate the market. After that, it rose to JD 107.7 million in 2017.

\section{Taxes on goods and services:}

According to the tax reforms adopted by Jordan since 1988, the local production fee was replaced by the consumption tax, and in 1994 the sales tax was abolished and replaced by the general sales tax, which was $7 \%$ on all goods and some services. It was then raised to $10 \%$ in 1995 , and in 2004 the law was amended to make the tax rate $16 \%$. The successive amendments to the General Sales Tax Law have led to the growth of the volume until it reached 2993.1 million JD in 2017. In recent years, there has been a fluctuation in sales tax rates and this is due to the changes made by the government. As the government resorted to imposing a special tax on oil derivatives, in which the taxes amount to about $38 \%$, to offset the impact of lower prices on sales tax.

Taxes on trade and international transactions (customs duties):

Jordan experienced a growth in trade taxes in the post2009 period as a result of the government's tightening in 
order to obtain more revenue from trade and goods taxes. Historically, in 1998, as part of its preparations to join the World Trade Organization (WTO), the Jordanian government lowered the minimum tariff on imported goods from $35 \%$ to $30 \%$, and these exemptions have contributed to the lower relative importance of taxes on merchants of total taxes. It canceled some exemptions to increase taxes from 285.6 million JD in 2012 to 325 million JD in 2013. It also notes a decline in 2017 to reach 304.3 million JD.

Tax burden in Jordan:
The tax burden decreased significantly after 2007 to reach 15.7 in 2017 , due to the exemptions granted by the Jordanian government to investors on the one hand, as well as the impact of the income tax law in 2009 which gave exemptions to individuals 12 thousand dinars, and the family 24 thousand dinars, which $95 \%$ of taxpayers were exempted, in addition to an increase in tax evasion, estimated at 695 million JD for 2012 (Jordan Economic and Social Council, 2014). Figure 2 shows that the tax burden decreased significantly in Jordan after 2007 to 15.7 in 2017.

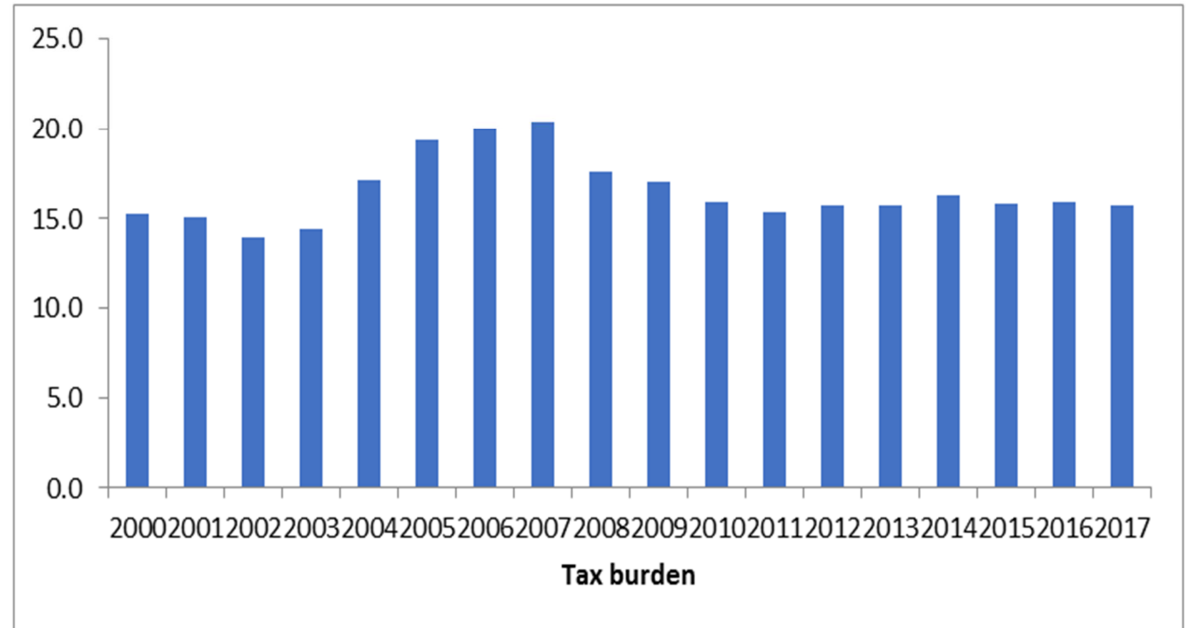

Source: Ministry of Finance Government Finance Bulletin, Different Volumes.

Figure 2. Tax burden (total tax to product ratio).

It is determined by this ratio whether the per capita burden corresponds to the increases in income, where the per capita burden is divided by per capita GDP. The tax burden was $15.7 \%$ in 2017 , meaning that the Jordanian citizen pays $15.7 \%$ of its share in GDP taxes to the government. This decrease is due to exemptions provided by the government to individual investors.
The tax burden of income tax; figure 3 shows that the tax burden reached about $3.3 \%$ in 2000 . The tax burden of income tax decreased in 2009 represented by the adoption of a unified tax system, which reflected negatively on the amount of tax collected in 2010-2011. More recently, in 2015, it introduced another amendment to the Income Tax Law that included changes in exemptions and rates.

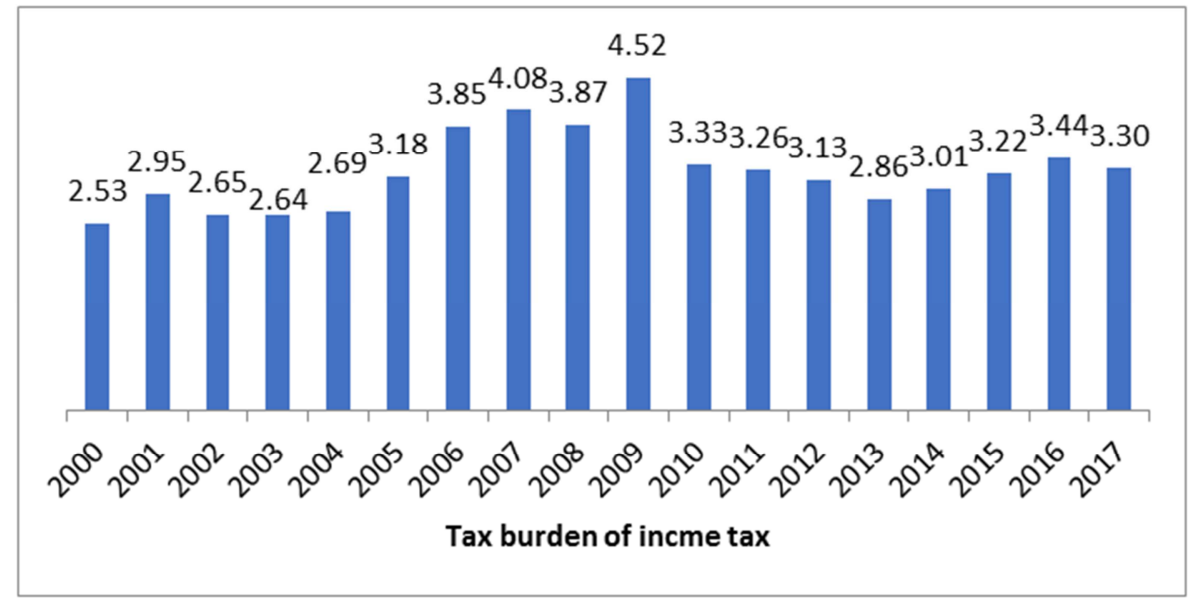

Source: Ministry of Finance Government Finance Bulletin, Different volumes.

Figure 3. Tax burden (income tax) during the period (2017-2000).

Comparing the tax burden of Jordan with some selected sample countries, we find that, as shown in Figure 4, Jordan is in the middle rank. Jordan ranked 8 out of 16 countries from the sample. Jordan is also lower than the Euro zone. 


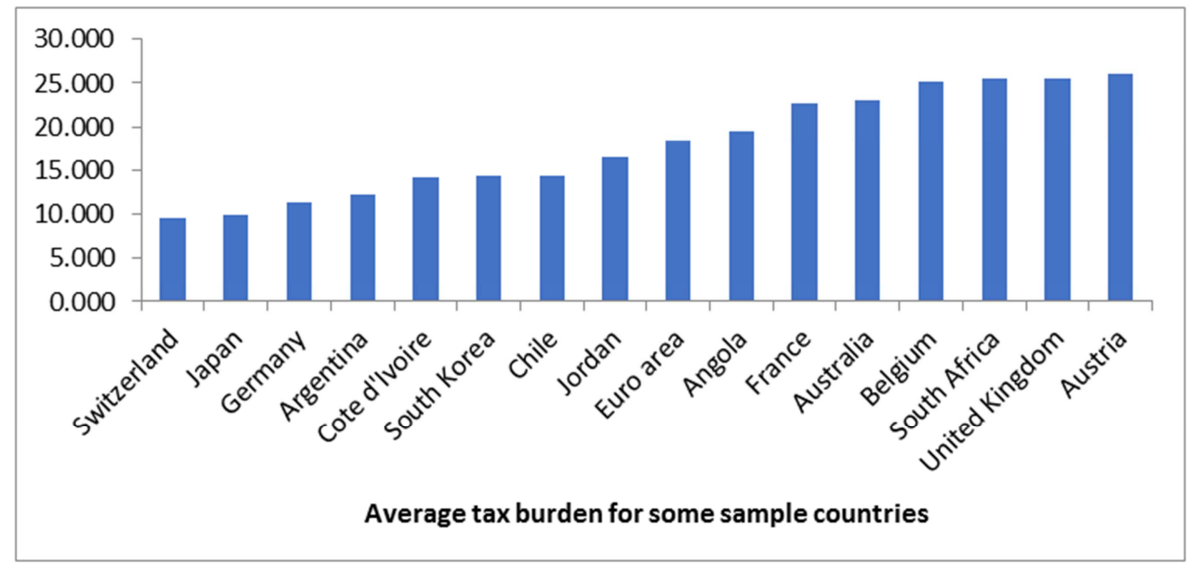

Source: World Bank, database, high development indicators.

Figure 4. Average tax burden compared to some countries during the period (2000-2017).

Table 1. Government revenues (central government, independent institutions and Social Security).

\begin{tabular}{|c|c|c|c|c|c|c|c|c|}
\hline & 2010 & 2011 & 2012 & 2013 & 2014 & 2015 & 2016 & 2017 \\
\hline Tax revenue & 2986 & 3153.6 & 3447.8 & 3756.4 & 4147.8 & 4213.3 & 4381.4 & 4471.9 \\
\hline Tax on income and prophits & 624.6 & 667.4 & 688.3 & 681.9 & 766.3 & 858.7 & 944.7 & 938.4 \\
\hline General sales tax & 1997.8 & 2033.2 & 2274.7 & 2532.9 & 2811.4 & 2780 & 2883.8 & 2993.1 \\
\hline Tax on foreign trade & 285.6 & 287 & 285.6 & 324.9 & 327.3 & 333.5 & 311.1 & 304.3 \\
\hline Direct taxes & 702.6 & 742 & 813.6 & 898.6 & 1009.1 & 1099.8 & 1186.5 & 1174.5 \\
\hline Indrict taxes & 2283.4 & 2320.2 & 2560.3 & 2857.8 & 3138.7 & 3113.5 & 3194.9 & 3297.4 \\
\hline Social security revenues & 796.3 & 824.6 & 946.2 & 1033.9 & 1178.2 & 1331.9 & 143.6 & 1749.2 \\
\hline Total domestic revenue & 4261.1 & 4198.9 & 4726.9 & 5119.8 & 6031.1 & 5910.6 & 6233.6 & 6717.6 \\
\hline Gross domestic product & 18762.01 & 20476.59 & 21965.5 & 23851.6 & 25437.14 & 26637.4 & 27444.9 & 28448.5 \\
\hline Direct tax burden & 15.9 & 15.4 & 15.7 & 15.7 & 16.3 & 15.8 & 16 & 15.7 \\
\hline$x$ Tax burden of income ta & 3.3 & 3.3 & 3.1 & 2.9 & 3 & 3.2 & 3.4 & 3.3 \\
\hline Tax burden of sales tax & 10.6 & 9.9 & 10.4 & 10.6 & 11.1 & 10.4 & 10.5 & 10.5 \\
\hline Tax burden of foreign trade tax & 1.5 & 1.4 & 1.3 & 1.4 & 1.3 & 1.3 & 1.1 & 1.1 \\
\hline
\end{tabular}

Source: Ministry of Finance, Government Finance bulletin. Different volumes.

\section{Previous studies:}

Many Arab and foreign studies have dealt with the measurement of tax capacity and tax effort. The IMF has played a prominent role in this regard, laying the foundations for measuring tax capacity in developing countries. These studies also vary in their inventory of the determinants of tax capacity and the variables that represent those factors as well. The studies that contributed to new additions to this topic will be addressed as follows:

The study [10] determined the main determinants of the effort and tax burden, using the time series method during the period (1981-2014) in Algeria. The study found that the tax effort index is relatively stable, as the actual tax revenue is equal to the potential tax revenue, pointing out that Algeria cannot collect more tax revenue in the current economic situation.

In a study [15], this study aims to measure the burden, energy and tax effort in Jordan within a comprehensive framework that takes into account all the associated impacts and implications. This is by estimating the general variance of momentum for cross-sectional data for 49 countries during the period 2000-2013. The results showed an inverse relationship between the tax burden and the share of the agricultural sector in the GDP, while it was positive with both the growth rate of the population, per capita GDP, the index of institutional quality in the country and the degree of trade openness. Estimating the tax effort has shown the results of using Jordan's data in the standard model estimated to reach the tax effort of 1.29 in 2008, after which it decreased to 1.03 in 2013. Therefore, the tax effort in Jordan is higher than the value of one, which means that there is a tax fatigue. The study [13] aimed to address the determinants of tax effort in general and estimate the tax effort index for Jordan in the period (1990-2013). The standard analysis model was used to estimate tax capacity taking into account a number of determinants, and the study uses FGLS-SUR as a method of data analysis.

The study found that there is a direct correlation between the tax effort and economic openness, pointing to the fluctuation of the tax effort values during the study period due to the continuous amendments in the tax laws and legislation, and the study recommended not to impose additional taxes at this time. The study [16] examined the burden and tax effort of the EU-FISHCARD countries in the period (1992-2013), which includes fourteen European countries (Czech Republic, Poland, Slovakia, Hungary, Germany, France, Britain, Spain, Italy, Belgium, Sweden, Denmark, Finland and Portugal).

The results of the study found the positive impact of public spending on education on tax capacity, and there is a positive 
impact of government debt on government capacity because the government uses tax revenues to pay debts, while there is a negative impact of inflation on tax capacity, as this inflation reduces the real value of tax revenues. The study [17] aimed to determine the voltage and tax capacity of (113) countries, where the study found that many countries are close to tax power, the study has used in the estimation of tax energy variables degree of development in the country, the volume of trade, education, Inflation, income distribution, corruption index, and leniency of tax collection. The results of the study found that these variables had significant effects in determining the level of tax capacity. A study [18] assessed the tax burden and tax effort for For a group of countries using cross-sectional data for (110) countries during the period (1994-2004), and using macroeconomic variables, demographic variables and institutional indicators.

The results of the study reached the classification of countries into four groups that constitute: (1) countries with low tax collection and burden (2) countries with high tax collection and high tax burden, (3) countries with low tax collection and high tax burden, (4) countries with high tax collection and low tax burden. The study suggested several solutions for countries that want to reform their tax systems, especially those with a high tax burden. In a study [9], it aimed to estimate the tax effort and tax capacity by using a standard cross-sectional model for (96) countries, and using variables including per capita GDP, trade volume, education, inflation, income distribution, and added value For the agricultural sector as a proportion of GDP, and an indicator of corruption.

The results of the study reached to identify countries that exceeded the level of tax energy, and also found that there is a direct correlation between the tax burden with both the per capita share of GDP, trade, and spending on education, while there is an inverse relationship with both inflation and income distributions, The share of the agriculture and corruption sector. In a study, [19] this study aimed to investigate the causes and consequences of changes in the level of taxes in the United States after the war, and dealt specifically with the macroeconomic effects of fiscal policy, tax policy.

The results of the study concluded that changes in tax policy has a positive impact in facing other effects on the economy with regard to increasing government spending, addressing the budget deficit, and promoting economic growth in the long run. Also, changes in tax policy affect production and GDP, but it leads to lower investment in response for tax increases.[20] study examined measuring the tax burden in (16) Arab countries through cross-sectional data during the period (1994-2000), in light of the countries suffering from difficulties in collecting sufficient revenues in addition to the budget deficit. The results of the study found that there is a statistically significant effect for each of the per capita GDP and the share of both the agriculture and industry sector in the GDP and foreign trade (exports and imports) on the tax burden, as well as political variables such as the political system, the system of government, the efficiency of tax collection, and institutionalization in government.

Study Methodology:

Statistical and standard methods were used to calculate the tax effort, by calculating the tax burden from the data of the Jordanian economy, and then estimating a standard model for calculating tax capacity through the use of cross-sectional data for (59) countries during the period (2000-2017), by (1062) views. Where a model was estimated for the section data series (Panel Data), and then tax effort was calculated based on the tax burden and estimates of tax capacity, and the results were extracted using the Eviews program.

\section{Model of Tax Capacity Assessment in This Study}

The study measured the impact of a set of economic variables (GDP, tax revenue, the share of manufacturing industries in GDP, per capita GDP, the share of exports in GDP, and the share of public services in GDP) on tax capacity, through sing time series analysis during the period (2000-2017). Several studies have used a cross-sectional data analysis method to estimate countries' tax power because of their positive advantages in improving the efficiency of the estimate. As this method is considered to be one of the best methods for estimating and enables many tests and statistical treatments by adding it to the individual effects or the time effects in formulating the model or what is known as the fixed effects and the random effects. Consequently, and in accordance with the theoretical framework of the economic model for estimating tax capacity, the following model has been applied:

$$
T_{\text {it }}=\beta_{0}+\beta_{1} Y_{\text {it }}+\beta_{2} E_{i t}+\beta_{3} M_{i t}+\beta_{4} S_{i t}+u_{i t}
$$

Where T represents the ratio of tax to GDP, Y: per capita income, E: ratio of exports to GDP, $\mathrm{M}$ : ratio of manufacturing to GDP, $\mathrm{S}$ : ratio of services to GDP. $\mathrm{U}_{\mathrm{it}}$ : random variable, $\mathrm{i}$ : country, t: time.

The tax burden index analysis was not sufficient to analyze the tax fit. Accordingly, the concept of tax capacity or estimated tax burden is based on the ability of national income to bear taxes as an efficient analysis indicator. This indicator is also known as the maximum revenue that can be collected through taxes. Taking into account both the size and structure of GDP, the amount of public expenditures and the level of their productivity, as well as the ability of individuals to bear taxes and the ability of the government to collect them [8]. Hence, it was found that the tax capacity represents the tax burden that achieve a balance between the government's need for tax to cover its expenses, and its ability to collect those taxes, as well as the ability of individuals to pay taxes. Several studies have used a panel data-Cross Section Analysis method to estimate the tax power of countries due to their positive advantages in improving the estimation efficiency.

Unit Root Test:

To measure the Stationary of data (the unit root test) the 
unit of the study, there are popular tests, all of which rely mainly on the "Dickey Fuller Test" designed for testing time series data Stationary. The Chu (LLC) - Lin -Levin test will be used to fit it with the nature of the panel data. The null hypothesis is rejected and accepted based on the P-Value. If it is less than $5 \%$, the null hypothesis's rejected (Stationary data).

Table 2. Stationary data test.

\begin{tabular}{lll}
\hline Variable & Probability & Result of the test \\
\hline TB & 0.0037 & $\mathrm{I}(0)^{*}$ \\
GDP_E & 0.0059 & $\mathrm{I}(0)^{*}$ \\
GDP_Y & 0 & $\mathrm{I}(0)^{*}$ \\
GDP_M & 0 & $\mathrm{I}(0)^{*}$ \\
GDP_S & 0.0017 & $\mathrm{I}(0)^{*}$ \\
\hline
\end{tabular}

At the significance level of $1 \%$.

\section{Stationary data test results:}

The problem of cross-sectional datanot being stationary is one of the important issues and a starting point for analyzing any time data. Here, it was necessary to perform stationary datatest to verify that the time cross-sectional dataused is static over time using (Unit Root Test) which corresponds to the nature of the sectional data, Based on Chu and Lin, Levin (LLC) test to check if there is no unit root problem. The results of the variables static tests showed Table 1 the tax burden (TB), the exports share in the gross domestic product (GDP_E), the per capita gross domestic product (Y_GDP), the share of the manufacturing industries in the gross domestic product (GDP_M), and the share of services in the output the local gross (S_GDP) at the level (where the value $P$ values for the variables did not exceed $1 \%$.

Test between static or random effect:

The null hypothesis in this test is the random effect, and therefore the Chi-Sq test as shown in Table 3 indicates the rejection of the null hypothesis and the acceptance of the alternative hypothesis as the probability is less than $5 \%$, which means the fixed effect is the most appropriate for the analysis.

Table 3. Hausman test results.

\begin{tabular}{lll}
\hline estT Sq.CH & Probability & Results \\
\hline 4 & 0 & The effect is constant \\
\hline
\end{tabular}

Table 4. Results of model estimation of cross-sectional data using fixed effect.

\begin{tabular}{llll}
\hline Variables & The parameters & The value of test T & Probabilty \\
\hline GDP.E & 0.043217 & 2.352416 & 0.0189 \\
GDP.Y & 0.000000138 & -1.66713 & 0.0958 \\
GDP.M & -0.303147 & -3.13933 & 0.0017 \\
GDP.S & -0.23732 & -3.17989 & 0.0015 \\
C & 35.07439 & 6.862085 & 0 \\
AR $(1)$ & 0.735331 & 9.563042 & 0 \\
R $^{2}$ & 0.93 & & \\
R $^{2}$ ADJ- & 0.92 & & \\
D W- & 1.75 & & 0 \\
Test F & 201.178 & & 0 \\
\hline
\end{tabular}

At significance level 1\%, 5\%,10\%.

The results of estimating the model as shown in Table 4 showed a positive relationship between both the tax burden and the share of exports in GDP. While the relationship was inverse between the tax burden and the added value of the industries sector, remittances, per capita or individual income, and the share of services in GDP. As for the significance level of the model parameters, the $(\mathrm{T})$ test showed that there was significance for the model parameters where the probability was less than $(\% 1),(5 \%)$ and $(10 \%)$. The explanatory strength of the model (R2) showed a high explanatory power, where the value of (R2) reached $93 \%$ as (R2) measures the percentage of change of the independent variables of the dependent variable. In order to check the self-link problem then use the Watson - Durbin ( $\mathrm{w}-\mathrm{D})$ test to detect the existence of a serial link problem that occurs in most time series that are close to each other. The value of (D.W) in the model has reached (1.75), which means that there is no selflink or serial link problem.

Based on the estimated parameters, it can be seen that the increase by one unit in the services sector share and the added value of the industries and transfer sector, and per capita or per capita income in GDP leads to a decrease in tax capacity by 0.23 and 0.30 and 0.000000138 respectively and it confirms the inverse relationship previously assumed. Moreover, an increase of one unit in the share of the export sector in GDP leads to an increase in tax capacity by 0.4 and confirms the previous positive relationship.

Estimating the tax capacity and tax effort in Jordan.

Based on the model information as in Table 4, which was estimated through sectional data, Jordan's data were used only in the estimated model to generate the amount of tax capacity for the Jordanian economy as shown in Table 5, we find that the tax energy has decreased in the recent years and increased tax burden.

The estimated values of the tax effort clearly show that the tax effort in Jordan has exceeded the standard in recent years, indicating that the tax burden has exceeded the maximum.

Table 5. Tax burden, tax capacity, and tax effort in Jordan.

\begin{tabular}{llll}
\hline Year & \%tax burden & \%tax capacity & \%tax effort \\
\hline 2000 & 15.26 & 14.42 & 1.06 \\
2001 & 15.08 & 15.66 & 0.96 \\
2002 & 14.01 & 15.76 & 0.89 \\
2003 & 14.47 & 14.53 & 1.00 \\
2004 & 17.10 & 14.94 & 1.14 \\
2005 & 19.33 & 17.27 & 1.12 \\
2006 & 19.99 & 18.53 & 1.08 \\
2007 & 20.38 & 18.88 & 1.08 \\
2008 & 17.64 & 19.86 & 0.89 \\
2009 & 17.03 & 17.06 & 1.00 \\
2010 & 15.92 & 17.35 & 0.92 \\
2011 & 15.40 & 16.11 & 0.96 \\
2012 & 15.70 & 15.63 & 1.00 \\
2013 & 15.75 & 15.60 & 1.01 \\
2014 & 16.31 & 16.17 & 1.01 \\
2015 & 15.82 & 16.30 & 0.97 \\
2016 & 15.96 & 15.86 & 1.01 \\
2017 & 15.72 & 16.10 & 0.98 \\
\hline
\end{tabular}

Source: Ministry of Finance, Government Finance Bulletin. Different Volumes. The table was calculated by the researcher. 
It is noted from Table 5 that the tax capacity of the Jordanian economy, on average, reached $16.54 \%$ of GDP, while the tax burden was high until 2007, then was decreased slightly in 2010 as a result of the government making major amendments to the income tax law. It is also noted that the tax burden is close to the highest level. Note that there is an acknowledgment from the government of tax evasion. This is confirmed by some studies, which gives an indication that the government resorted to raising tax rates to cover tax evasion. Therefore, the class that pays taxes pays more than its taxable capacity. Especially the productive sectors, which is reflected negatively on the cost of financing and the required rate of return from those sectors. The results also indicate that the amendments to the tax law may have negative effects on the Jordanian economy. It will increase the tax burden imposed on the Jordanian economy to exceed the tax capacity. Therefore, it should not exceed $1.1 \%$ of GDP. Therefore, the tax effort in Jordan in recent years is higher than the value of one, which means there is tax fatigue.

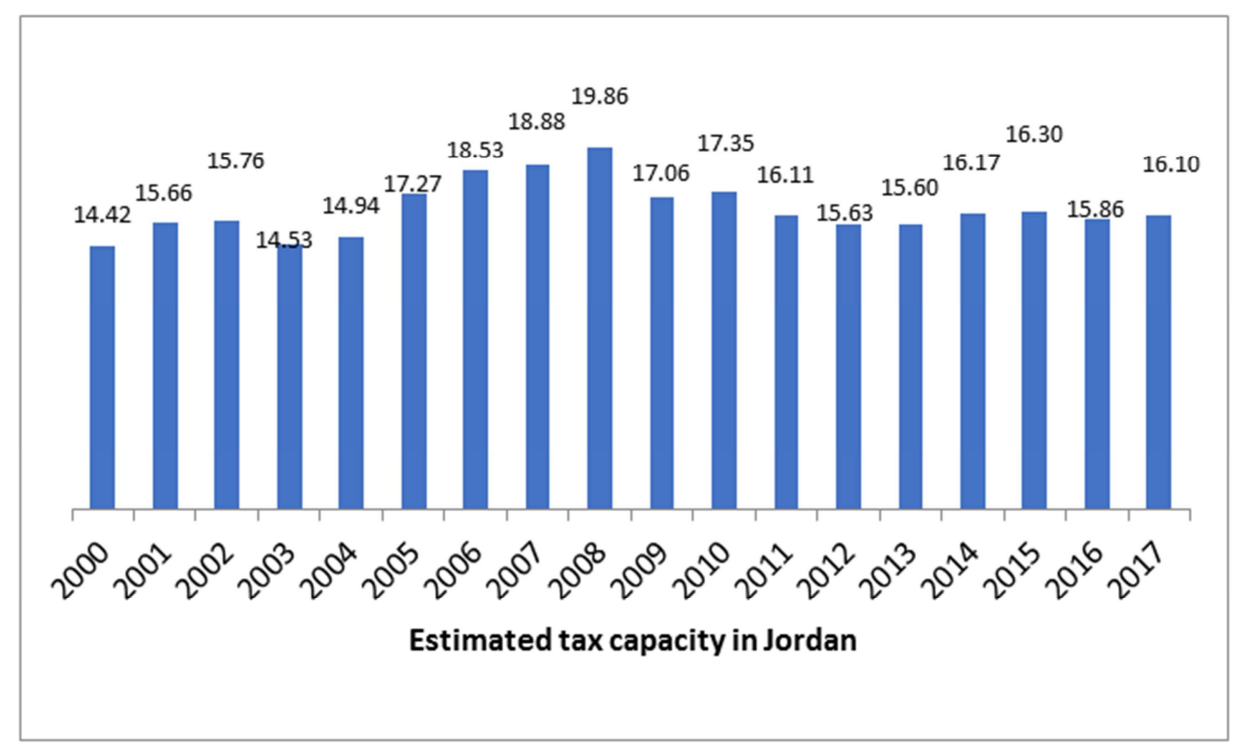

Source: The table was calculated by the researcher.

Figure 5. Tax capacity in Jordan during the period (2000-2017).

\section{Results}

The results of the analysis showed the following:

a) There is a positive relationship between the tax burden and the share of exports in GDP.

b) While the relationship was inverse between both the tax burden and the added value of the manufacturing sector and the per capita or per capita income and the service sector share of GDP.

c) Jordan is close to the upper limits of tax capacity, as the tax burden in 2017 was about $15.7 \%$, and if the impact of the measures has been considered by the government since the beginning of the year 2018, especially sales tax and special taxes on oil, this means that Jordan is close to tax fatigue.

d) Jordan's tax effort is high. This means that the class that pays taxes pays more than its tax capacity, and this is considered a stress for some sectors, especially the productive sectors, which has negative effects on the competitiveness of those sectors.

e) The tax capacity in Jordan has reached an average of $16.5 \%$ of GDP, and the government must take into consideration not to exceed these limits to avoid tax fatigue in Jordan.

\section{Recommendations}

The study recommended the following:

a) The importance of the effective utilizing of the tax capacity of individuals and the economy and maintaining acceptable levels of tax effort and not exceeding these levels.

b) The necessity to maintain the administrative effectiveness of the tax system and reduce tax burdens, and that the tax system be modern and keep pace with global economic development and according to the capability of citizens.

c) The amendment of the Income Tax Law in 2018 is an economic justification, but it should avoid entering the phase of tax fatigue.

\section{References}

[1] Al-Zawaghi, Najmi Moftah Amer (2017). Determinants of tax capacity and its impact on the Libyan economy. Journal of Financial, Accounting and Management Studies. (7).

[2] De Santis, Roberta; Mercuri, M.; Cristina. Vicarelli, Claudio. Taxes and location of foreign direct investment, Institute for Studies and Economic Analysis (ISAE), Rome, 2001. 
[3] Mankiw, N. Gregory. Macroeconomic, Worth Publishers, Fifth Edition, 2003.

[4] Dunken, Denvil\&Sabirianova Peter. Klara. Tax progessivity and income inequality. Georgia State University, Department of Economics. Andrew Young School of Public studies, 2008.

[5] Baer, Werner; Galvao, Antonio. Tax burden, government expenditure and income distribution in Brazil, CIBER series papers, 2005.

[6] Maroun, Warren. Does capital tax add to or detract from the fairness of south African tax system?, University of Witwatersrand, South Africa, 2010.

[7] Al Aroukoub, Hashem Mohamed, Sami, Mohamed (2006). The financing role of taxes in selected Arab developing countries for the period 1980-2002, Rafidain Development, 82, (28).

[8] Mirrlees, James. Dimensions of tax design, Institute for Fiscal Studies, Oxford University Press, 2010.

[9] Pessino, Carola \& Fenochietto, Ricardo. Determining countries tax effort, Hacienda Pública.

[10] Toufik Hadjmaoui \& Hanane Benatek. Tax Capacity and Tax Effort of Aleria from 1981 to 2014. Strategy and Development Review, 2018, 8 (15): 109-124.

[11] Le, Minh Tuan; Moreno-Dodson, Blanca; Bayraktar, Nihal. Tax capacity and tax effort extended cross-country analysis from 1994 to 2009", Policy Research Working Paper 625, The World Bank, 2012.

[12] Gupta Abhijit. Determinants of tax revenue efforts in developing countries. International Monetary Fund, Working Paper, 2007, 7 (184): 1-39.

[13] Bashayreh, AlaGhaleb. Tax Capacity and Effort and Economic
Implications: Evidence from Jordan. Jordan Journal of Economic Sciences, 2016, 3, (2): 179-191.

[14] The Economic and Social Council (2014). Tax evasion in Jordan, its causes, methods, and magnitude, Economic and Social Council, Amman, Jordan.

[15] Al-Majali, Ahmed Abdel-Qader. (2016). Capacity Estimation and Tax Effort in Jordan = Estimating Tax Capacity and Tax Effort in Jordan. Dirasat: Administrative Sciences, 161 (3988), $1-23$.

[16] Zdenka Zakova Kroupova; Josef Slaboch. Tax capacity and tax effort in Visegrad Group countries and in old member EU states. Conference: Theoretical and practical aspects of public finance, At Prague, Volume: XXI, 2015.

[17] Fenochietto, Pessino. Understanding countries' tax effort, International Monetary Fund, 2013, Working Paper No. $13 / 244$.

[18] The Ministry of Finance, The Public Finance Bulletin of the Jordanian Government.

[19] Christina Romer \& Romer, D. (2010). The Macroeconomic Effects of Tax Changes: Estimates Based on a New Measure of Fiscal Shocks, American Economic Review, Vol. 100, No. 3, 2010 .

[20] Eltony, M. Nagy. Measuring tax Effort in Arab countries, Arab planning institute, 2002.

[21] Española / Revista de Economía Pública, (195 4/2010): 6587.

[22] Center for Strategic Studies - University of Jordan in cooperation with the Amman Chamber of Commerce, Income Tax Law: An Assessment of Reality and Possible Alternatives, 2018. 